\title{
Electronic control card for transmission of mobile load crane type KRUPP
}

\section{Tarjeta de control electrónica para transmisión de grúa de carga móvil tipo KRUPP}

\author{
CABRERA-ORNELAS, Javier†'*, MARTÍNEZ-ZAMORA, Juan Alberto, MARTÍNEZ-MONTALVO, \\ Anselmo and HERNÁNDEZ-NARVÁEZ, Ana Luisa
}

\section{Instituto Tecnológico de Jilotepec}

ID $1^{\text {er }}$ Autor: Javier, Cabrera Ornelas / ORC ID: 0000-0002-9398-1498, CVU CONACYT ID: 692074

ID $1^{\text {er }}$ Coautor: Juan Alberto, Martínez Zamora / ORD ID: 000-0002-4245-5711

ID $2^{\text {do }}$ Coautor: Anselmo, Martínez Moltalvo / ORC ID: 0000-0003-3404-2463

ID $3{ }^{\text {er }}$ Coautor: Ana Luisa, Hernández Narváez / ORC ID: 0000-0003-4500-7209

DOI: $10.35429 / J I O .2019 .4 .3 .28 .34$

Received May 28, 2019; Accepted June 30, 2019

\begin{abstract}
The design, modification and control of machinery and industrial equipment plays a very important role in any company, where machinery and / or equipment is found which are out of operation due to the lack of an electrical / electronic control part which possibly By the model of the machinery and / or equipment is no longer manufactured or is difficult to achieve. This causes economic losses due to having the machinery out of operation. This article presents a proposal to replace the computer corresponding to the operation of the transmission of a mobile telescopic load crane, which consists of using an Arduino programming board for the control part and to obtain the necessary logical sequence of the different transmission speeds, power electronics (power transistors) were used for the power stage through which the necessary voltage and current levels are obtained to which the electrovalves corresponding to the different speeds of the transmission operate. As shown in the content of the work control is very accessible, so, it could be implemented in a sustainable way in other vehicles that have an automatic transmission with changes in speeds through electrovalves.
\end{abstract}

Control, Crane, Transist

\section{Resumen}

El diseño, modificación y control de maquinaria y equipo industrial juega un rol muy importante en cualquier empresa, donde se cuenta con maquinaria y /o equipo el cual se encuentran fuera de funcionamiento por la falta de una parte eléctrica/electrónica de control la cual posiblemente por el modelo de la maquinaria y/o equipo ya no se fabrica o es difícil de conseguir. Esto ocasiona pérdidas económicas por tener la maquinaria fuera de funcionamiento. En este artículo se presenta una propuesta para sustituir la computadora correspondiente al funcionamiento de la transmisión de una grúa de carga telescópicas móviles, la cual consiste en utilizar una placa de programación Arduino para la parte de control y poder obtener la secuencia lógica necesaria de las diferentes velocidades de la transmisión, se utilizó electrónica de potencia (transistores de potencia) para la etapa de potencia mediante la cual se obtienen los niveles de voltaje y corriente necesarios a los cuales operan las electroválvulas correspondientes a las diferentes velocidades de la transmisión. Como se muestra en el contenido del trabajo el control es muy accesible, por lo que, se podría implementar en forma sustentable en otros vehículos que cuenten con una transmisión automática con cambios de velocidades a través de electroválvulas.

Control, Grúa, Transistor

Citation: CABRERA-ORNELAS, Javier, MARTÍNEZ-ZAMORA, Juan Alberto, MARTÍNEZ-MONTALVO, Anselmo and HERNÁNDEZ-NARVÁEZ, Ana Luisa. Electronic control card for transmission of mobile load crane type KRUPP. JournalIndustrial Organization. 2019. 3-4: 28-34

\footnotetext{
*Correspondence to Author (javier.cabrera@ hotmail.com)

$\dagger$ Researcher contributing first author.
} 


\section{Introduction}

Programmable control through electronics for process control is important today for most companies or applications where precise control is required, it is a fundamental tool in the areas of industrial, commercial and residential engineering.

As already mentioned, there are several electronic equipment such as Programmable Logic Controllers, LabVIEW software which control almost all industrial processes and applications with great precision but are expensive equipment and in many cases require the payment of a license. The alternative presented is the use of the Arduino programmable electronic card which is low cost, reliable, versatile and does not require a license for programming the control sequence.

The method presented in this work to perform the control stage for the operation of the crane transmission consists of an Arduino card that through its digital inputs and outputs can obtain the logic of operation of the transmission to control the inputs of activation of an electronic semiconductor device TRANSISTOR and to be able to activate the power stage of the solenoid valves.

Due to the low consumption that a transistor requires for activation, the control circuit can use any of the many low-cost solidstate devices such as capacitors, resistors, semiconductor diodes, optically coupled devices and integrated circuits.

The content of this work shows that this type of control for automatic processes is truly practical and versatile which can be applied sustainably in any industrial automation process where the need is to program a process manually or automatically by simply changing the programming. This work is intended to replace the original computer which moves the transmission of the crane.

\section{Development and construction of the electronic card}

This section explains the function of each element and the reason for its choice.

\section{Arduino Plate One}

Arduino is a free hardware platform based on a flat panel with a microcontroller, designed to facilitate the use of electronics in multidisciplinary projects, in this project it was used to program the logic of the input and output signals.

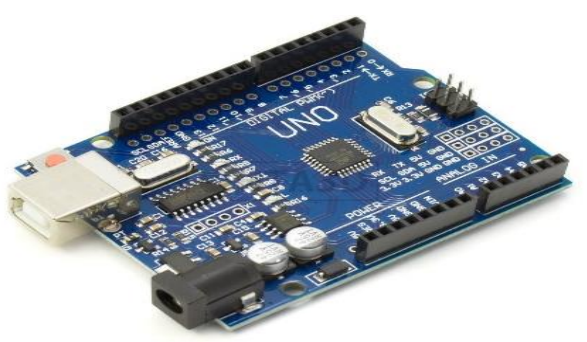

Figure 1 Arduino plate

Source: www.electronicaymas.com,2019

\section{Moc- PC817}

A Moc is an optocoupler. That works with an infrared led and an internal phototransistor, the purpose is to isolate the control stage from the power stage.

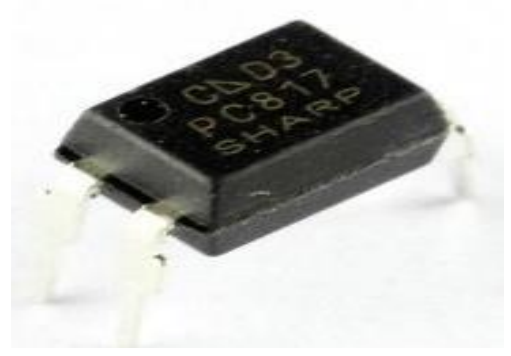

Figure 2 Moc PC817

Source: www.farnell.com

\section{Mosfet IRF630}

A mosfet is an electronic semiconductor device used for signal switching and amplification. This semiconductor will be used for the power stage.

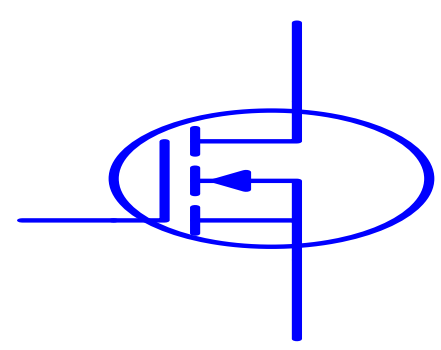

Figure 3 Mosfet IRF630

Source: Own Elaboration 


\section{Semiconductor diode}

The diode is a semiconductor device which allows the passage of electrons in only one direction. The diode will be used to protect the Mosfet from a possible return of current in the power stage.

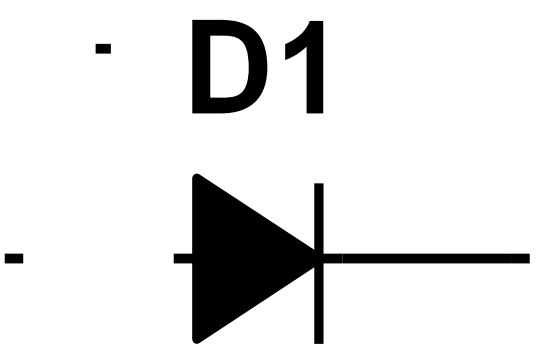

Figure 4 Semiconductor diode Source: Own Elaboration

\section{Zener diode}

It is an electronic device whose main function is to use it as a voltage regulator or as a voltage reference

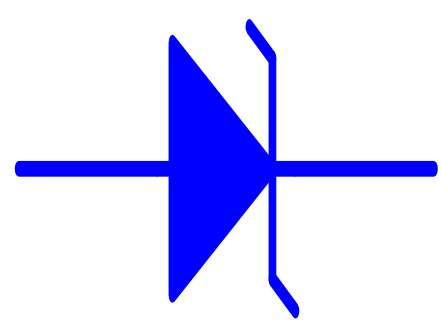

Figure 5 Zener diode

Source: Own elaboration

\section{Relay}

A relay is an electromechanical switch. It works by energizing a coil which produces a magnetic field that produces the closing or opening of mechanical contacts which are used for the activation of alternating current (AC) or direct current (CD) devices.

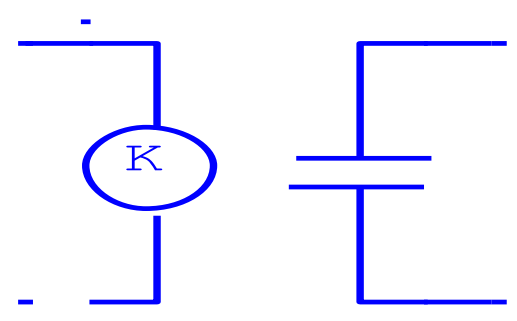

Figure 6 Relay

Source: Own Elaboration

\section{Methodology to develop}

The electronic card was designed thinking that the sequence of input and / or control output can be changed or reprogrammed for future modifications in modern crane models which present this problem.

Recall that the Arduino card represents a programming system in $\mathrm{C}$ language for applications that require the acquisition, control, analysis and presentation of analog, digital and PWM data.

\section{Control stage}

The control stage consists in programming the combinational logic in the Arduino card, the truth table of the speed transmission (Vel) can be seen in table 1 . This table was obtained directly from the crane operation manuals.

\begin{tabular}{|l|l|l|l|l|l|l|l|l|l|l|l|}
\hline Vel & \multicolumn{1}{|c|}{ Inputs } \\
\hline R2 & 1 & 0 & 0 & 0 & 1 & & 1 & 0 & 1 & 1 & 0 \\
\hline R1 & 1 & 1 & 0 & 0 & 1 & & 1 & 1 & 0 & 1 & 0 \\
\hline N & 0 & 0 & 0 & 0 & 0 & & 0 & 0 & 0 & 0 & 0 \\
\hline D & 0 & 1 & 0 & 0 & 1 & & 1 & 0 & 0 & 0 & 1 \\
\hline 5 & 0 & 1 & 0 & 1 & 1 & & 0 & 0 & 1 & 0 & 1 \\
\hline 4 & 0 & 1 & 1 & 0 & 0 & & 1 & 0 & 0 & 1 & 1 \\
\hline 3 & 0 & 1 & 0 & 1 & 0 & & 0 & 0 & 1 & 1 & 0 \\
\hline 2 & 0 & 1 & 0 & 1 & 1 & & 1 & 1 & 0 & 1 & 0 \\
\hline 1 & 0 & 0 & 1 & 1 & 1 & & 0 & 1 & 1 & 0 & 0 \\
\hline
\end{tabular}

Table 1 Real crane operation table Source: Own Elaboration

The purpose of programming is to obtain the combination of outputs through the digital terminals of the Arduino board based on the combination of digital inputs, where R1 and R2 represent the two reversals, $\mathrm{N}$ neutral, $\mathrm{D}$ driver and 1,2,3,4, 5 transmission speeds.

\section{Signal conditioning stage}

In general, conditioning of the analog and / or digital signals is necessary in an appropriate manner for the following stages of the operation. The signal may be too small so it would be necessary to amplify it or possibly the signal is large, so its magnitude would have to be reduced; the signal can be analog and digitization is required; be digital and convert it to analog, voltage signal and convert it to current or a current signal convert it to a voltage signal. All these possible signal modifications are known as signal conditioning. 


\section{Conditioning of input signals}

In this project we will deal with the conditioning of digital signals input to our system, these signals come from the different transmission changes, these signals are $24 \mathrm{Vdc}$ so it is necessary to condition these signals to $5 \mathrm{Vdc}$ since the digital inputs of Arduino are $5 \mathrm{Vcd}$. Fig. 7 shows the electronic circuit used for conditioning the digital input signals to the system.

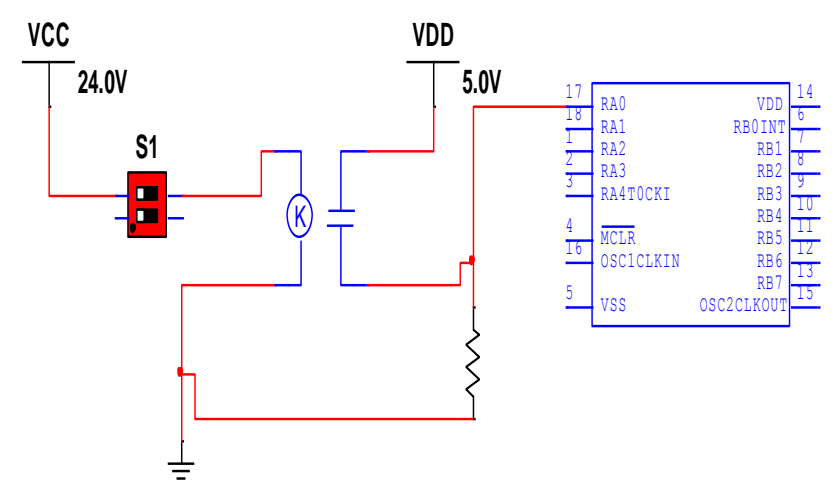

Figure 7 Conditioning of digital input signals.

Source: Own Elaboration

\section{Conditioning of output signals}

The purpose of conditioning the output signal is to take the digital output signal from the control system (Arduino) which is $5 \mathrm{Vdc}$ to a $24 \mathrm{Vdc}$ digital signal. In fig. 8 the electronic circuit used in the output stage can be observed.

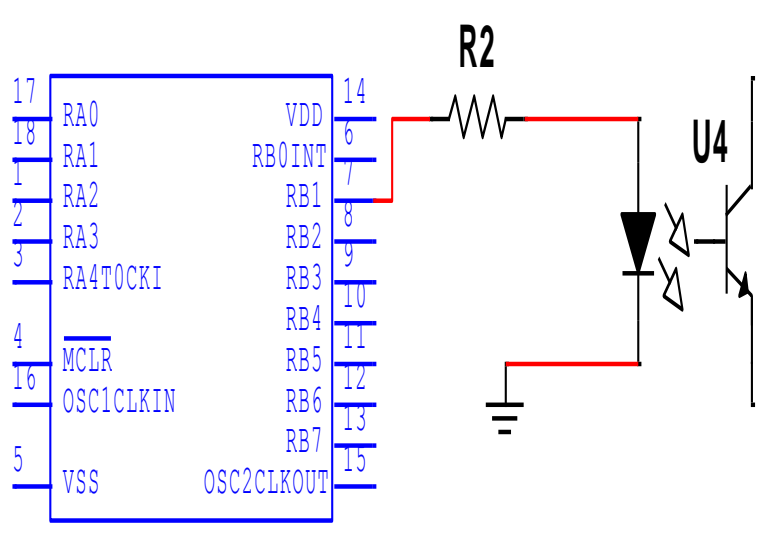

Figure 8 Conditioning of digital output signals. Source: Own Elaboration

At this stage it was possible to electronically condition both the input to the 24 $\mathrm{Vdc}$ system with the Arduino digital inputs of $5 \mathrm{Vdc}$, as well as a successful conditioning of the Arduino output of $5 \mathrm{Vdc}$ with the outputs of the 24Vdc system.

\section{Arduino digital signal coupling with the system power stage}

Sometimes digital systems control the power systems through an interconnection, in the gate of the TRANSISTORS which act on resistive or inductive loads and are used for lighting control or speed control of industrial motors. The use of power where currents that exceed the Amper are handled, it is necessary to keep in mind the electrical safety of the people first and secondly the protection of the control system.

The connection between the control system and the power system is desirable by means of technologies in which there is no physical (electrical) connection between the two systems, currently the above is possible through the use of OPTO COUPLERS since an optical coupling is achieved and an electrical insulation The reason for thinking about an optical coupling is to protect the control stage from a possible leakage current of the power stage. The control system can vary between intelligent programmable devices such as (microprocessors, microcontrollers, programmable logic devices or computers).

\section{Experimental coupling development}

In diagram 1 you can see the block diagram of the coupling.

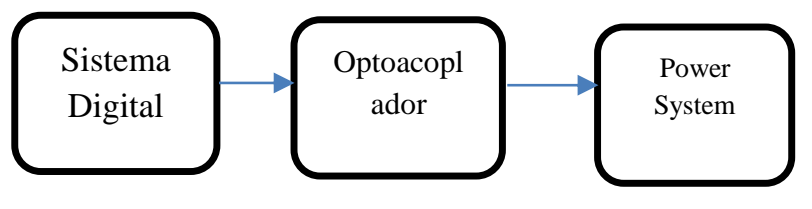

Diagram 1 block block diagram Source: Own Elaboration

The electronic circuit design is shown in fig. 9 .

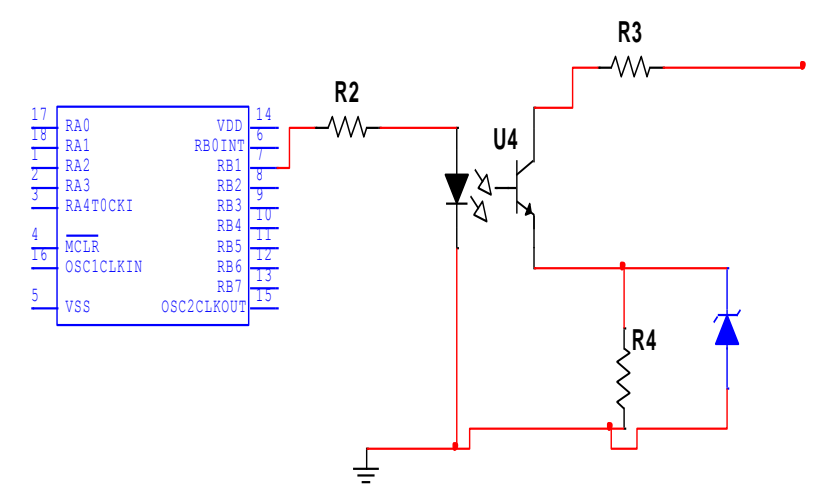

Figure 9 Electronic optocoupler circuit Source: Own Elaboration

CABRERA-ORNELAS, Javier, MARTÍNEZ-ZAMORA, Juan Alberto, MARTÍNEZ-MONTALVO, Anselmo and HERNÁNDEZ-NARVÁEZ, Ana Luisa. Electronic control card for transmission of mobile load crane type KRUPP. Journal-Industrial Organization. 2019 
Although the circuit of fig. 9 is simple, it is very useful because it allows the power stage to be activated safely with a small digital DC signal. The optocoupler separates the power output from the right side of the control input from the left side.

In conclusion, optocoupling is always necessary to guarantee electrical insulation. The optocoupler is a very simple and inexpensive electronic device, with a wide variety of coupling types.

\section{Power stage}

This stage involves the use of a Mosfet transistor since these devices are faster than other devices used in power electronics (thyristors, bipolar transistor, etc.). Mosfet transistors currently have a wide application with logic gates in digital electronics. The circuit of the figure. 10. Show the power stage.

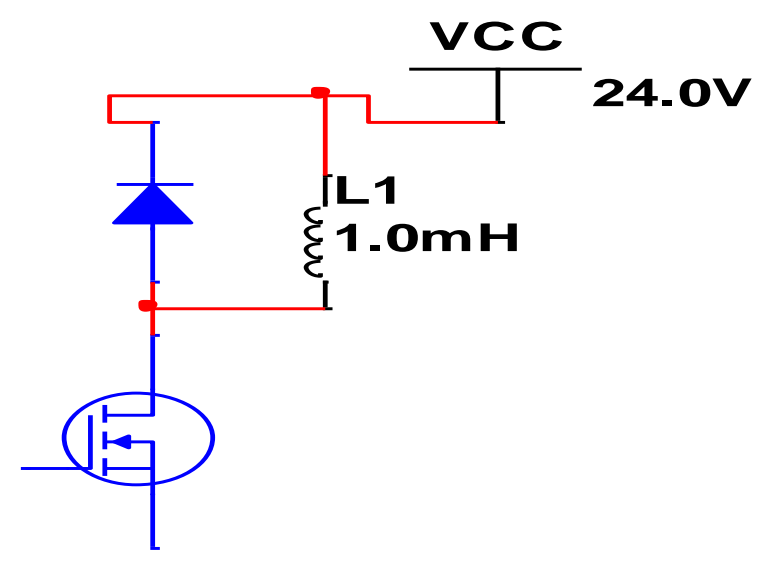

Figure 10. Electronic power stage circuit Source: Own Elaboration

Figure 11 shows the complete electronic circuit comprising the integration of the control stage, conditioning stage and the power stage. With this third stage of power, the complete project is completed with positive results.

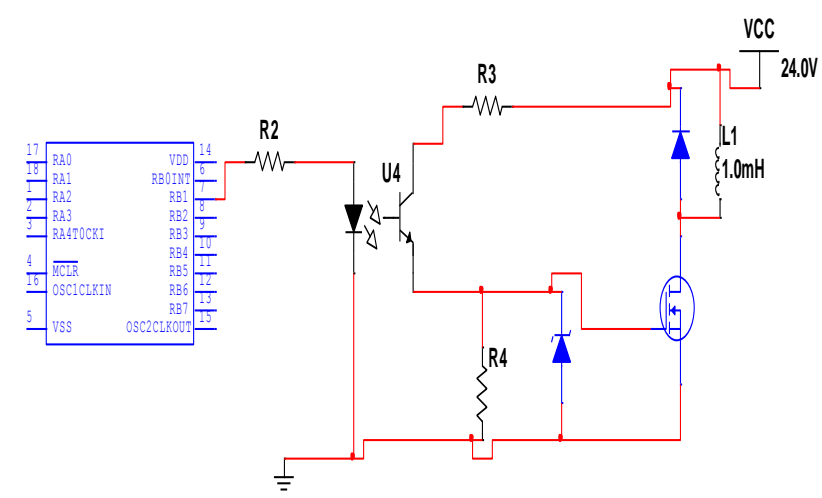

Figure 11. Electronic circuit stage integration.

Source: Own Elaboration

\section{Mathematical development}

The morfet transistor can be used in three operating modes that are:

$\begin{array}{ll}- & \text { Saturation } \\ - & \text { Period } \\ - & \text { Cut }\end{array}$

Our interest is to use it in the cutting mode since in this mode the Mosfet behaves as a switching element.

Transfer functions

The following equation defines the relationship between Id and Vgs

$I_{d}=I_{d s s}\left(1-\frac{V_{g s}}{V_{P}}\right)^{2}$

Where:

Id is the maximum current when $\mathrm{Vgs}=0$

Vgs is the control variable.

$\mathrm{Vp}$ and Idss are constant.

It is worth mentioning that when Vgs = Vp la Id $=0 \mathrm{~mA}$

From the device specification sheet you can get some electrical parameters such as:

Vgs and Vp in shutdown state.

Idss in power state.

You of your nominal values. follows:

The polarization equations are as

$V_{d s}=V_{d}-V_{s}$

$I_{d}=\frac{I_{d s s}}{4}$

$V_{g s}=\frac{V_{p}}{2}$

\section{Annexes}

The following figures show the finished physical card. 

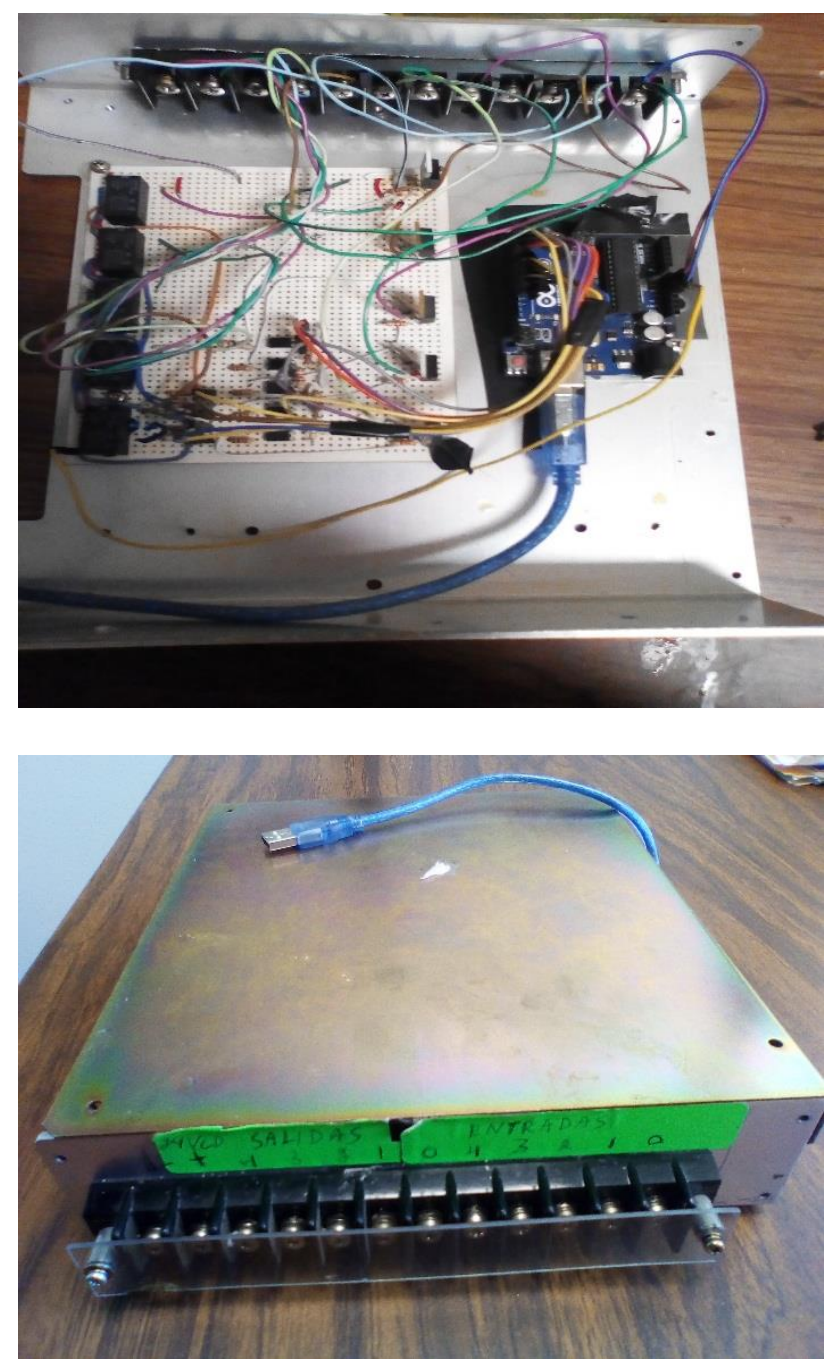

\section{Acknowledgement}

The first author thanks the Technician of higher studies of Jilotepec for the institutional support and of his laboratories for the necessary tests for the accomplishment of this work of technological development.

\section{Results}

No previous work or manufacturing history was found. The first prototype of the electronic card was finished and tested.

The results obtained were favorable since laboratory tests were carried out where loads were connected with the actual characteristics of the crane transmission solenoid valves.

Field tests were performed where the results were favorable.

The total costs are quite ambitious since they range between $\$ 4,000.00$ and $\$ 5,000.00$ pesos and if it is added that in many cases this type of control is no longer manufactured it has an added value.
This first prototype was developed in bakelite, later it will be developed on a board (PCB) for its greater presentation and functionality The realization time was 30 business days.

The power consumption is approximately half Amper (0.5 Amper).

The biggest gain is in the cost.

\section{Conclusions}

The logic program was designed according to the truth table of the crane transmission which is microprocessor engraved on the Arduino card. With the method proposed in this technological development work, the logic of the truth table can be varied or reprogrammed according to the needs of any other crane model only by changing the software and not the hardware. The results obtained can be applied in general to vehicles that have a computer for their operation which includes a combinational logic.

The developed card is of the utmost importance since there are currently cranes that, due to the failure of the transmission computer, are towed by other cranes to the area of operation, so this is a card is a solution so that the cranes can be transport again by themselves reducing costs and reducing insecurity in their transfer.

For future studies or improvements it is recommended to replace the relays with semiconductor devices as well as the exchange of the Arduino card for an industrial automaton since they are more reliable, robust and their life time is much longer.

The possible disadvantages of this methodology is that the Arduino card is of the didactic type and not for industrial use, so the conditioning of inputs and outputs of 24 to $5 \mathrm{Vdc}$ was necessary, which could be avoided with a programmable automaton of the industrial type.

It is worth mentioning that the circuit of figure 11 is for an input signal and an output of five inputs and five outputs in total with what the card has and that are activated independently according to the logic programmed in the Arduino card. 


\section{References}

Albert Malvino y David J. Bates. Principios de electrónica Editorial McGraw-Hill, España, 2007

Antonio Hermosa Donate. Electronica aplicada Editorial Alfaomega, México 2013

\begin{tabular}{|c|c|c|c|}
\hline \multirow{2}{*}{\multicolumn{2}{|c|}{$\begin{array}{l}\text { Boylestad Robert } \\
\text { Louis. Electrónica. } \\
\text { de Circuitos. Editorial }\end{array}$}} & & $\begin{array}{r}\text { Nashelsky } \\
\text { Teoría }\end{array}$ \\
\hline & & Prentice & Hall \\
\hline
\end{tabular}

Conseil, D. I, (2019). Diseño e implementación de sistemas de transporte por cable para comunicaciones de difícil acceso.

http://www.datasheetcatalog.net/es/datasheets_ $\mathrm{pdf} / \mathrm{M} / \mathrm{O} / \mathrm{C} / 3 / \mathrm{MOC} 3010 . \mathrm{shtml}$

http://www.onsemi.com/pub_link/Collateral/BT A08-600BW3-D.PDF

Llanga, B., \& Ivan, K. (2019). Prototipo de un ascensor y su control comarando tecnologías diferentes de accionamiento.

Maloney J. Timothy. Electrónica Industrial. Dispositivos y Sistemas. Editorial Prentice Hall Hispanoamericana, México, 2000

Manual de reemplazos ECG. Silvania, USA, 2000

Rubio Lorenzada, Á. (2019). Sensorización de máquinas y generación de datos en la nube para aplicaciones de industria 4.0.

Ruiz Figueroa, J. I. Diseño de un sistema portátil tipo cometa para generación de electricidad.

Solano, O. R. (2019). Proyectos de Grado modalidad Desarrollo.

Williams,

Arthur. Microprocesadores, dispositivos optoelectrónicos, periféricos y de interfaz. Serie de circuitos integrados. Mc Graw Hill, México, 1989. 